\title{
ガスメーター用ダイヤフラムの長期信頼性評価
}

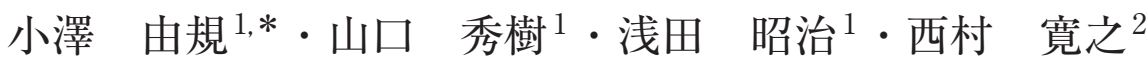

\section{Long-term Reliability Evaluation of the Diaphragm for Gas Meters}

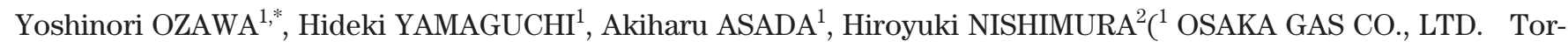
ishima, Konohana-ku, Osaka, 554-0051, Japan. ${ }^{2}$ Kyoto Institute of Technology Hashinoue, Matsugasaki, Sakyo-ku, Kyoto, 606-8585, Japan)* y-ozawa@osakagas.co.jp

To establish a technique for reproducible instrumental error variation on the plus side of diaphragm gas meters, diaphragms collected from the field were examined so as to determine the major cause of instrumental error variation on the plus side. The authors then carried out tests to reproduce instrumental error variation on the plus side, studying the conditions for a test of accelerated degradation equivalent to 20-year use. As a result, the authors found that the major cause of instrumental error variation on the plus side is diaphragm thermal degradation. The authors also confirmed that the accelerated heat aging conditions that replicate the state of a diaphragm after 20-years' use are 2000 hours at $70^{\circ} \mathrm{C}$ and 6000 hours at $60^{\circ} \mathrm{C}$.

(Received on February 5, 2013)

(Accepted on May 22, 2013)

Key Words : Gas meter, diaphragm, rubber, reliability, accelerated degradation test, Arrhenius plot

\section{1. 緒}

\section{言}

地球環境保全と資源有効利用の観点から，リサイクル法 に基づきマテリアルリサイクル等の取り組みが積極的に行 われているが, 部品リユースは使用履歴が不明で, リユー 又時の性能担保が困難であり, 費用がかかる等の理由から ほとんど行われていない ${ }^{1)}$. 著者らは, 部品リユースに適 した機器として,

- 設置後 10 年以内に全数回収され，回収品の市場経過年 数が均一である.

・同一規格の単体製品である.

・回収ルートが確立している.

などの特徴を有するガスメーターに着目し，ガスメーター 部品の耐久性に関する研究に取り組んでいる ${ }^{2-6)}$.

ガスメーターは計量法に規定される特定計量器であり, 検定有効期間ごとに交換される．家庭用を主とする 16 号 以下のガスメーターの場合, 検定を受けた翌月 1 日から起 算して 10 年間が検定の有効期限であり, 大阪ガス管内で 約 700 万戸の拄客様宅のガスメーターは設置後 10 年以内に 全数回収される.その後, ガスメーターは一部部品を修
理・交換された後にリユースされるが，個々の部品の使用 期限の判断は各ガス会社およびメーターメーカーに任せら れてきた。ガスメーターは計量器であるとともに, 地震や ガス漏れなどの異常を感知する機能をもつ保安機器である ため, リユース品でも新品と同等の品質が要求され, ガス メーター部品の製品寿命を適切に見極め可能な評価手法が 必要とされている.

従来，一般家庭用ガスメーターとして主流の膜式ガスメ ーターの耐久性評価には, 使用最大流量で膜式ガスメータ 一を数千時間駆動し，その前後の計量性能を確認する駆動 部耐久試験が採用されてきた ${ }^{7}$. ガスメーター部品の機械 的な摩耗劣化の促進に有効な試験と考えられる. しかしな がら, 本手法では, 膜式ガスメーターの経年劣化（屋外設 置環境下，10年間）によるマイナス側の器差変化は再現 できるが，プラス側の器差変化を再現できないとの課題が あった。また, 膜式ガスメーターのプラス側の器差変化を 再現可能な評価手法に関する報告例は見当たらない，器差 とは計量器自体の有する誤差であり, 次の式 (1) で表さ れる。ここで，Eは器差 (\%)，Iは被検定ガスメーターの 指示量 $(\mathrm{L}), Q$ は基準器の指示量 $(\mathrm{L})$ である. 膜式ガス 


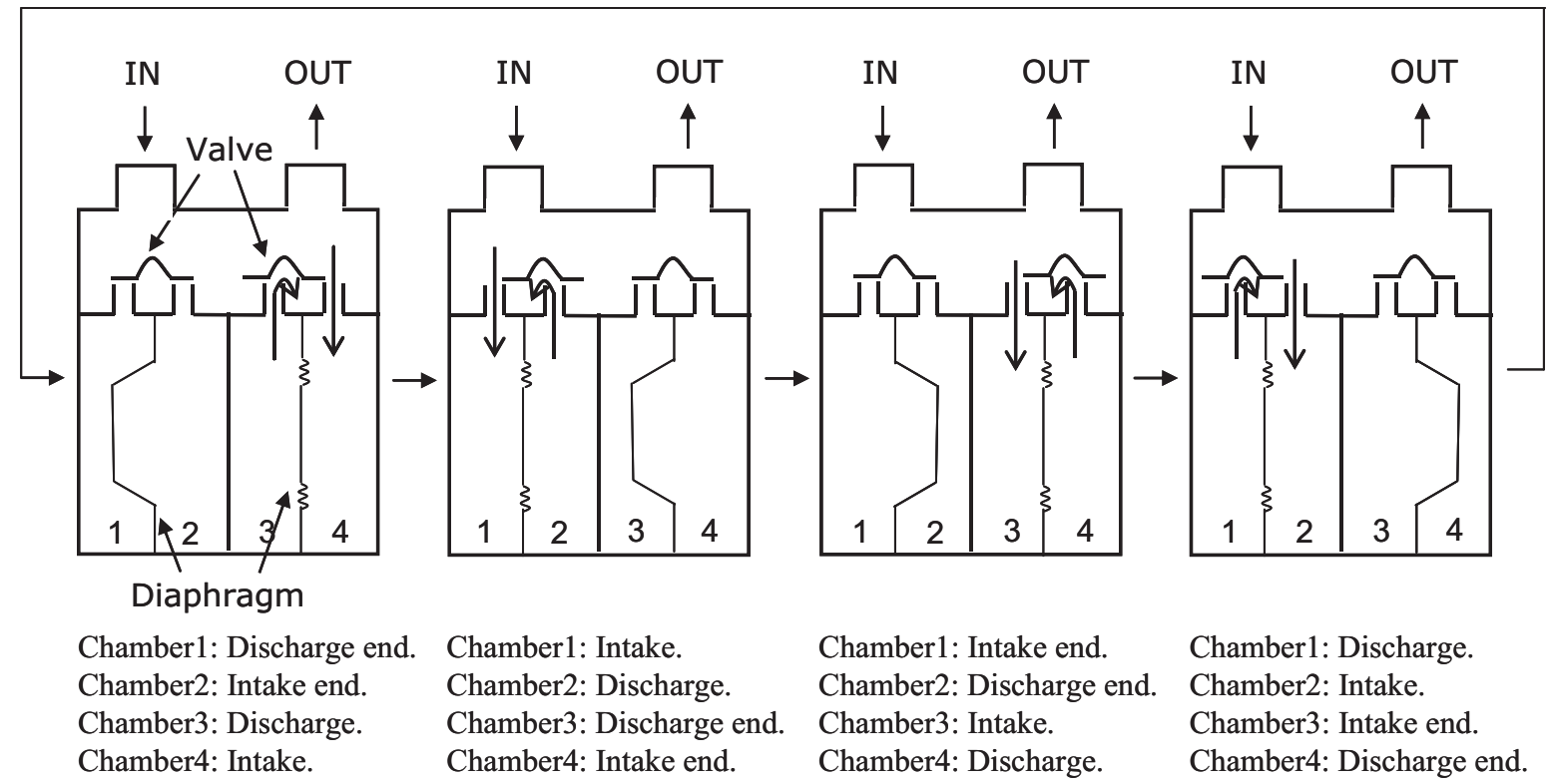

Figure 2 Principle of gas meter by means of diaphragms

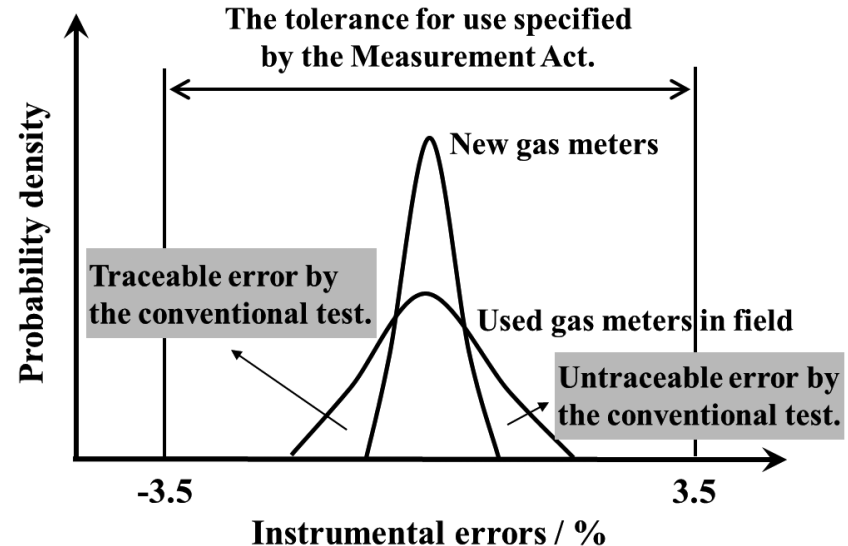

Figure 1 Instrument error of gas meters

メーターの新品および 10 年使用品（1回検定満期品）の器 差分布の概念図を Figure 1 に示す．10年使用品の器差分 布は，使用公差（計量法で規定されるガスメーターの許容 誤差）の範囲内であるが，新品と比較すると，マイナス側 とプラス側の両側に広がる。一方で, 前述の通り, 従来の 評価手法である駆動部耐久試験は，マイナス側の器差変化 は再現可能であるが，プラス側の器差変化は再現不可能な ものであった。

$$
E=\frac{I-Q}{Q} \times 100(\%)
$$

本研究では, 膜式ガスメーターのプラス側の器差変化を 再現可能な評価手法を明らかにすることを目的として，主 要部品の1つであるダイヤフラムに着目し, 膜式ガスメー ターの 10 年使用品抒よび 20 年使用品（2回検定満期品） の市場回収品の分解調查から, ダイヤフラムの劣化機構の 解明を試みた．その後，ダイヤフラムの劣化機構と膜式ガ スメーターのプラス側の器差変化の関係を考察し，促進劣

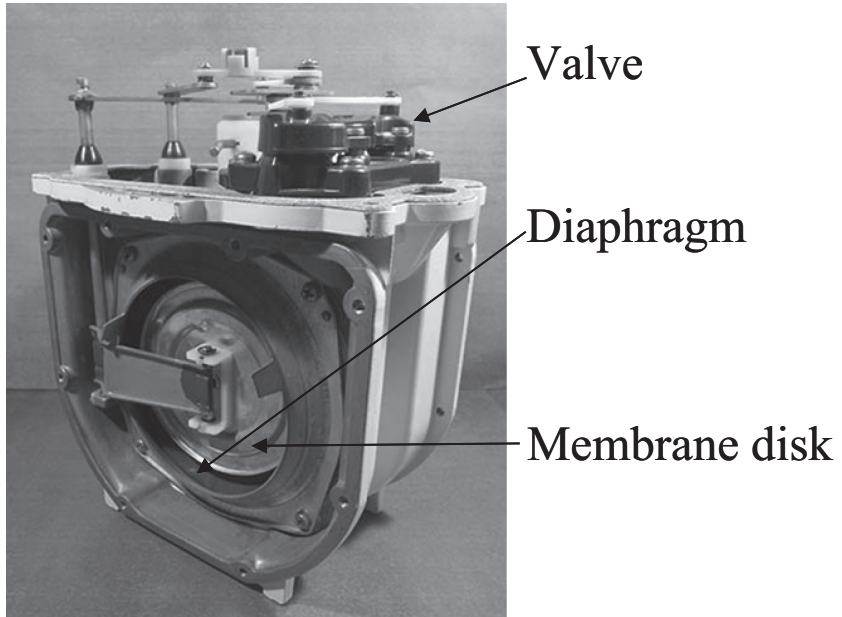

Figure 3 Internal diaphragms parts in a gas meter

化試験によるプラス側の器差変化の再現試験に取り組ん だ。また，ガスメーター設置環境下におけるダイヤフラム の 20 年相当の促進劣化試験の条件検討を行った.

\section{2. 膜式ガスメーターの基本構造}

\section{1 膜式ガスメーターの計測原理}

膜式ガスメーターは，2枚のダイヤフラムに仕切られた 4つの計量室, 各々の計量室へのガスの吸排気を行うため の 2 つスライド弁, ダイヤフラムとスライド弁をタイミ ングよく連動させるための連動機構, 連動機構の回転を伝 達してガス積算量を計測表示する積算機構から構成され る. 膜式ガスメーターの計測原理を Figure 2 に示す. ガ スは膜式ガスメーター入口から入り, スライド弁を通り, 1つの計量室に入る (吸気)。その過程において, ガス差 圧によりダイヤフラムが動き，ダイヤフラムを隔てて反対 側の計量室では, 充満されていたガスがスライド弁を経て 
膜式ガスメーター出口から排出される（排気）。また，も う 1 枚のダイヤフラムは連動機構が $90^{\circ}$ 位相がずれて動 き，同様にガスの吸気・排気を行う．Figure 2 に示す一連 の動作を繰り返すことで，膜式ガスメーターはガスを連続 的に計量する。したがって，膜式ガスメーターの計量精度 は, ダイヤフラムの諸特性に大きく依存すると考えられる。

膜式ガスメーター内部の外観写真を Figure 3 に示す. ダイヤフラムの中央部分に添設される円形の膜板は, ダイ ヤフラム反転時の変形挙動を安定化させるものであり，ダ イヤフラムの両面に取り付けられている。 また，大阪ガス 管内でのダイヤフラムの使用期限は 20 年である.

\section{2 ダイヤフラムの基本特性}

ダイヤフラムは，ゴムと基布からなる複合部材である。 ゴムの主成分はアクリロニトリル-ブタジエンゴム（NBR） とエピクロロヒドリンゴムであり，NBRは耐油性，耐摩 耗性および耐熱劣化性に優れ，エピクロロヒドリンゴムは 耐寒性に優れることが一般的に知られている。両者のブレ ンド比の最適化により,ガスメーター設置環境下において, ダイヤフラムは長期間にわたり要求性能を満足することが できる．また，基布の主成分は耐熱性および強度に優れる ポリエチレンテレフタラート（PET）であり，ダイヤフ ラム反転時の変形挙動を安定化させる機能を担っている. ダイヤフラムの劣化要因としては，ゴムの熱劣化や疲労劣 化 ${ }^{8)}$ ，およびゴム中の添加剤減少による硬化劣化等が考え られる。

\section{3. 実験}

\section{1 膜式ガスメーター市場回収品の分解調査}

都市ガス用膜式ガスメーターの 10 年使用品および 20 年 使用品を各50台市場から回収し, それらを分解し取出し たダイヤフラムに対して, 膨潤試験, 外観観察を行った. また，一部のダイヤフラムに対しては，動的粘弾性測定お よび引張試験を行った。回収したダイヤフラムは外径約 $130 \mathrm{~mm}$ の皿型をしており, その膜厚は約 $0.2 \mathrm{~mm}$ であっ た。

膨潤試験は, ダイヤフラムの周辺部分から幅 $15 \mathrm{~mm}$ 長 さ30 $\mathrm{mm}$ の平板状試験片を基布の織り方向に対してバイ アス方向で採り, 試験片を $20{ }^{\circ} \mathrm{C} 24$ 時間トルエンに浸漬し, 手早く濾紙でふき取った後に 24 時間室温放置した。その 過程において，試験片の試験前の重量 $(a)$, トルエン浸漬 後の重量（b）拈よび取出後 24 時間放置後の重量（c）を 電子天科で測定し，測定值から次の（2）式および（3）式 で表される重量変化率（\%) を算出した。（2）式はゴム中 に含まれる可塑剤等の添加剤に関連し，值が大きいほどゴ ム中に添加剂が多く残存することを意味する。（3）式はゴ ムの架橋度に関連し，值が大きいほどゴムの架橋度が小さ
いことを意味する.

$$
\begin{aligned}
& \frac{a-c}{a} \times 100(\%) \\
& \frac{b}{c} \times 100(\%)
\end{aligned}
$$

動的粘弾性測定は, 新品 2 枚および 20 年使用品 3 枚に対 して, ダイヤフラムの周辺部分から基布の織り方向に対し てバイアス方向で幅 $5 \mathrm{~mm}$ 長さ $40 \mathrm{~mm}$ の平板状試験片を 採り，(株）ユービーエム製の Rheogel-E4000を使用 し, $-50{ }^{\circ} \mathrm{C}$ から $20{ }^{\circ} \mathrm{C}$ の測定範囲において, 昇温速度 $5{ }^{\circ} \mathrm{C} /$ $\min$ で行った. 測定周波数は, 膜式ガスメーターの駆動周 波数を考慮し， $2 \mathrm{~Hz}$ とした。

引張試験は，新品， 10 年使用品および 20 年使用品に対 して, ダイヤフラムの周辺部分から基布の織り方向に対し てバイアス方向でJIS 6251 ダンベル状 7 号試験片を採り, (株）インストロン製の万能試験機 5567 を使用し，100 $\mathrm{mm} / \min$ の引張試験速度で行った. サンプル数は各 10 枚 とした。

\section{2 膜式ガスメーター器差変化の再現試験}

膜式ガスメーターのプラス側およびマイナス側の器差変 化を再現するため, 膜式ガスメーターの促進劣化試験に取 り組んだ。促進劣化試験は, プラス側の器差変化の再現の ために熱加速試験を行い, マイナス側の器差変化の再現の ために従来の評価手法である駆動部耐久試験を行った。熱 加速試験は, 膜式ガスメーターを駆動させず, 静止状態に て行った. 熱加速試験条件は, ダイヤフラムの基布の主成 分であるPETのガラス転移温度を超えない温度範囲とし, $50{ }^{\circ} \mathrm{C} 4000$ 時間および $70{ }^{\circ} \mathrm{C} 4000$ 時間の 2 条件とした。駆 動部耐久試験は，使用最大流量（以下， $Q \operatorname{max）である~} 3$ $\mathrm{m}^{3} / \mathrm{h}$ で空気を供試メーターに通して, 室温で 4000 時間ま で駆動させた。また，ダイヤフラムの温度と繰り返し変形 の複合ストレスとして， $Q \max$ で空気を供試メーターに 通して, $50{ }^{\circ} \mathrm{C} て ゙ 4000$ 時間までの駆動も行った，供試メー ター数は各 5 台とした。促進劣化試験の後, 供試メーター の器差および計量室体積を測定した。比較対象として, 新 品 5 台の器差および計量室体積の測定も行った.

器差の測定は，供試メーターの下流側に基準ガスメータ 一を接続し, 特定計量器検定検査規則（平成 5 年通商産業 省令第 70 号）第 10 章第 2 節使用中検査及び同規則附則の 関連規定に規定された方法によって行った。試験流量は $Q$ $\min (=0.05 \times Q \max ), 3 \times Q \min , 0.1 \times Q \max , 0.2 \times$ $Q \max , 0.4 \times Q \max , 0.7 \times Q \max , Q \max$ とし, 供試メ 一ターの器差は, 各流量点における器差の平均值とした.

計量室体積の測定は, 供試メーターの計量室の出入口の 一方を大気開放，他方を水柱ゲージに接続し，ダイヤフラ ムに外気と $5 \mathrm{mmH}_{2} \mathrm{O}$ の差圧がかかるように水圧で調整 
し， $5 \mathrm{mmH}_{2} \mathrm{O}$ の差圧を正圧と負圧でかけた場合の水柱ゲ ージの変化分（ダイヤフラムが前後に移動することで変化 した体積）を測定した。

\section{3 ダイヤフラムの熱加速試験の条件最適化}

ガスメーター設置環境下に打けるダイヤフラムの 20 年 相当の熱加速試験の条件検討に取り組んだ。ダイヤフラム の加速評価パラメータとして，ゴム中の添加剤の残存量お よびダイヤフラムの $T_{g}$ に着目した。これらの值が 20 年使 用品と同等になるように，熱加速試験の条件を特定した。

ゴム中の添加剤の残存量の検討では，ダイヤフラムの周 辺部から幅 $15 \mathrm{~mm}$ 長さ $30 \mathrm{~mm}$ の平板状試験片を基布の織 り方向に対してバイアス方向で採り，試験片を $60{ }^{\circ} \mathrm{C}, 70$ ${ }^{\circ} \mathrm{C} ， 80{ }^{\circ} \mathrm{C}$ の恒温槽に放置した後に膨潤試験を行い，(2) 式で表される重量変化率を算出し，ゴム中の可塑剤等の添 加剤の残存量を求めた。試験片の放置時間は，各温度で 200 時間，500 時間，1000 時間，2000 時間，4000 時間， 6000 時間， 8000 時間である。サンプル数は各 5 とした。

ダイヤフラムの $T_{g}$ の検討では，ダイヤフラムの周辺部 分から幅 $5 \mathrm{~mm}$ 長さ $40 \mathrm{~mm}$ の平板状試験片を基布の織り 方向に対してバイアス方向で採り，試験片を $70{ }^{\circ} \mathrm{C}$ の恒温 槽に放置した後に動的粘弾性測定を行った．試験片の放置 時間は 1000 時間，2000 時間，4000時間である。サンプル 数は各 1 とした。

Table 1 Swelling properties of diaphragm materials A) The relevant values to the amount of residual additives in rubber.

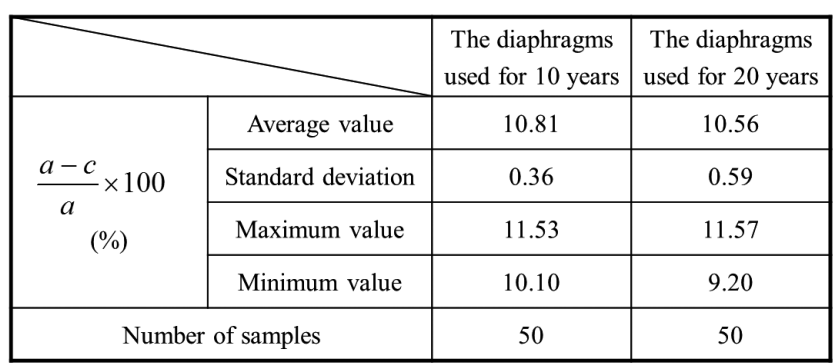

B ) The relevant values to cross-linking density of rubber.

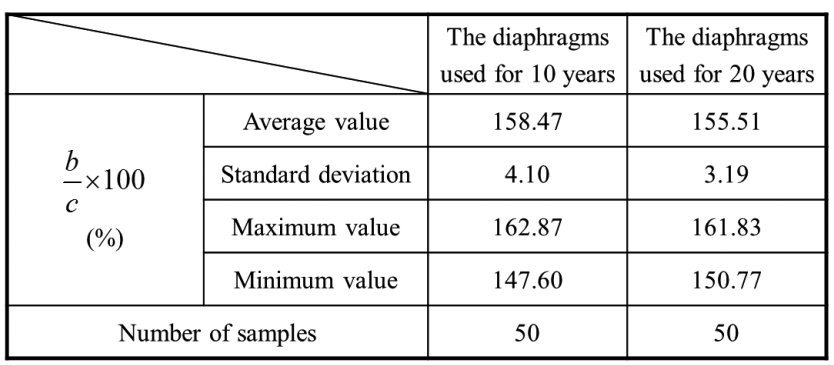

a: The specimen weight before immersion

b: The specimen weight after immersion in toluene for 24 hours

c: The specimen weight after drying at room temperature for 24 hours

\section{4. 結果および考察}

\section{1 膜式ガスメーター市場回収品の分解調查}

ダイヤフラムの 10 年使用品 50 枚, 20 年使用品 50 枚の膨 潤試験の結果を Table 1に示す. Table 1の A）から，10 年使用品と比較して 20 年使用品は，（2）式で表される重 量変化率の平均值が小さく，分布が値の小さい側に広がっ ており，ゴム中の可塑剤を含む添加剤が減少傾向にあるこ とがわかった。また，Table 1のB）から，10年使用品と 比較して 20 年使用品は，（3）式で表される重量変化率の 平均值が小さく，ゴムの架橋度が増加傾向にあることがわ かった。

ダイヤフラムの新品 2 枚および 20 年使用品 3 枚に対し て，動的粘弾性測定を行った結果を Figure 4 に示す。縦 軸の損失正接 $\tan \delta$ は貯蔵弾性率 $E^{\prime}$ と損失弾性率 $E^{\prime \prime}$ の比で あり，損失正接 $\tan \delta\left(=E^{\prime \prime} / E^{\prime}\right)$ の極大值から得られる

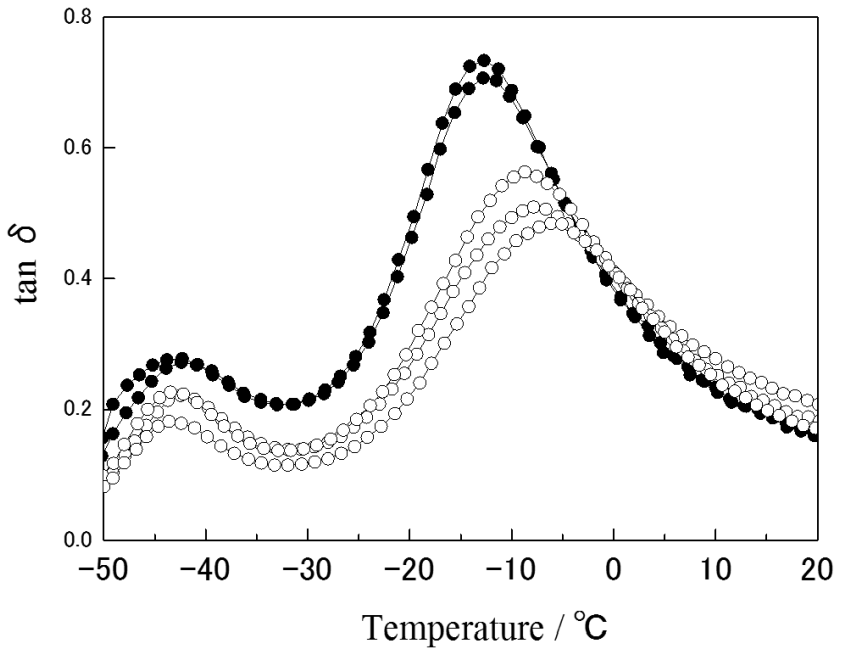

New diaphragms ; $O$, Diaphragms used for 20 years

Figure 4 Temperature dependence of tangent delta of diaphragm materials used for 20 years and new ones
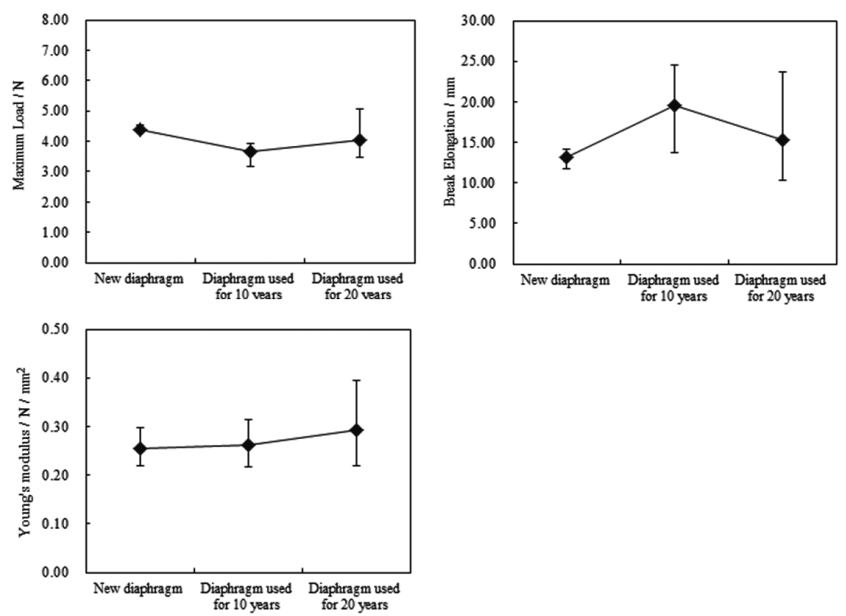

Figure 5 Elongation properties of diaphragm materials used in field and new one 


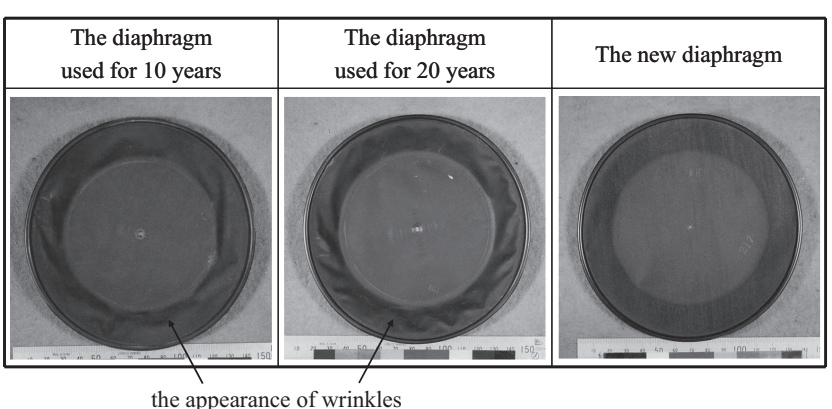

the appearance of wrinkles

Figure 6 Used diaphragms in field and new one



Figure 7 Relationship between degradation of diaphragm and positive instrument error

温度がガラス転移温度（以下， $T_{g}$ ）に相当する．測定の結 果，損失正接 $\tan \delta$ のピークは，低温側 (新品： $-42{ }^{\circ} \mathrm{C}$ ) と高温側（新品：-12 ${ }^{\circ} \mathrm{C}$ ）の 2 つることがわかった。 ダイヤフラムのゴムは 2 種のブレンドであり，低温側のピ ーク温度は耐寒性に優れるエピクロロヒドリンゴムの $T_{g}$ であり，高温側のピーク温度はNBRの $T_{g}$ であると推測さ れる ${ }^{9)}$ 。また，新品と比較して，20年使用品では高温側の ピーク温度がー $6{ }^{\circ} \mathrm{C}$ 付近まで上昇することが確認された. NBRの二重結合部の切断・再架橋による硬化および可塑 剤の揮発が進行し，ゴムの低温特性が低下したためと考え られる。

ダイヤフラムの新品， 10 年使用品および 20 年使用品に 対して引張試験を行い，荷重変位曲線から最大荷重，破断 伸び，ヤング率を求めた結果を Figure 5 に示す。ヤング 率は, 荷重変位曲線の初期の傾きから算出した. 各項目と もに，新品と市場回収品で顕著な值の変化は確認されなか ったそその理由として，ダイヤフラムはゴムと基布の複合 部材であり，試験片の破断時にはゴムよりも基布の影響を 強くうけたためと推測される。引張試験は，ガスメーター 用ダイヤフラムのゴムの経年劣化の評価パラメータとして 適切でないことがわかった。

10 年使用品および 20 年使用品の外観観察では，外観上 の顕著な変化として，ダイヤフラムの周辺部分に「しわ」 が生じているものが散見された。「しわ」は，ゴムの硬 化・収縮が進行した結果，基布が引っ張られて局所的に変 形したものと見受けられた。「しわ」が生じていた 10 年使 用品抢よび 20 年使用品の代表的なもの，比較対象として 新品の外観写真を Figure 6 に示す. ダイヤフラムの周辺 部分において，新品では確認されない「しわ」が，10年 使用品および 20 年使用品で確認された。また，その程度

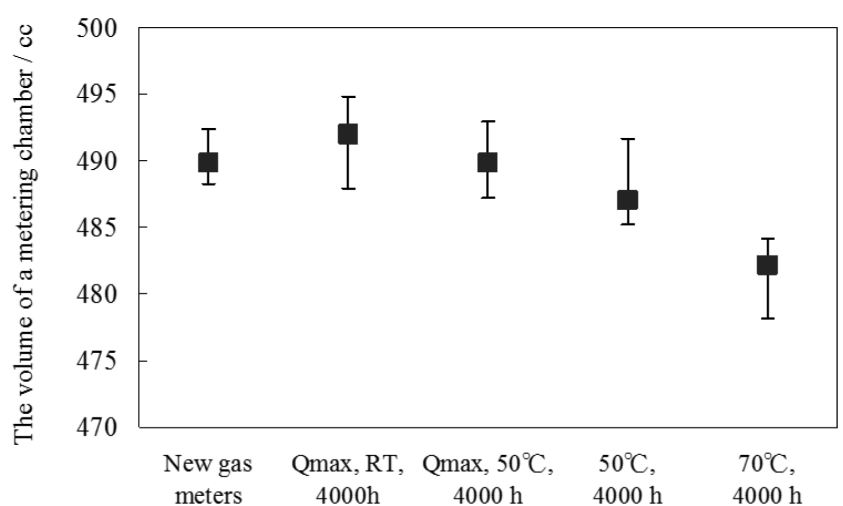

Figure 8 Measured volume in chamber after degradation test

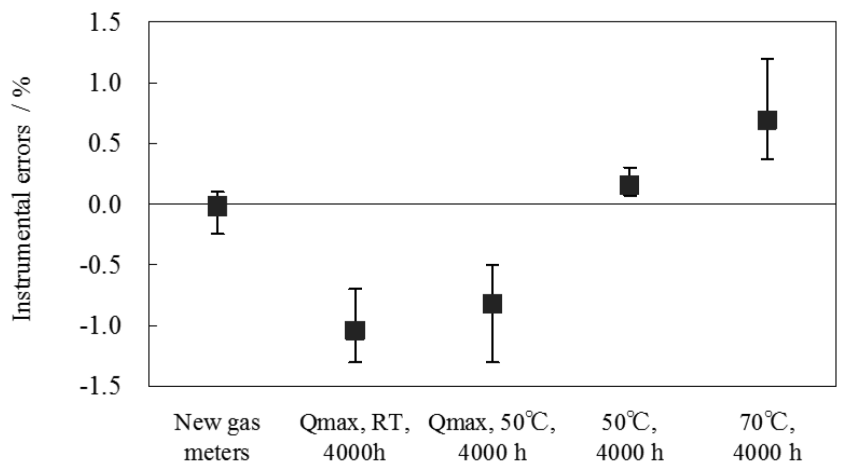

Figure 9 Instrument error after accelerated degradation test

は，20年使用品がより顕著であった。なお，「しわ」が生 じていないダイヤフラムの中央部分は, ダイヤフラム反転 時の変形挙動を安定化させる膜板が添設されていた箇所で ある。

市場回収品の分解調查の結果から，ダイヤフラムの周辺 部分において，温度の影響によりゴム中の可塑剤の揮発お よびゴムの架橋が促進され，ゴムの硬化・収縮に基布が引 っ張られた結果，「しわ」が形成されたと推測される。ダ イヤフラムの劣化の主要因として温度を想定したのは，屋 外で使用されるガスメーターは直射日光に唒されることが 多く，ガスメーター内部が高温に晒される環境にあること や，ガスメーター内部は都市ガスで充満されており，ダイ ヤフラムが酸素，湿度，紫外線の影響を受けにくい環境に あることを考慮したためである。また，ダイヤフラムは PET 製基布によりゴムの伸縮を抑える構造になっており， 疲労劣化に対する耐久性が高いことも考虑した。ゴムの硬 化・収縮によりダイヤフラムに「しわ」が形成されると， 膜式ガスメーターの吸気過程におけるダイヤフラムの拡張 が制限されるため，計量室の体積は縮小する，計量室の体 積が縮小すれば，膜式ガスメーターは本来よりも多く吸 気・排気工程を繰り返すことになり，器差はプラス側に変 化すると考えられる．想定されるダイヤフラムの劣化機構 と膜式ガスメーターのプラス側の器差変化の関係を Figure 7 に示す. 




Figure 10 Diaphragms after accelerated degradation test and field use for 20 years

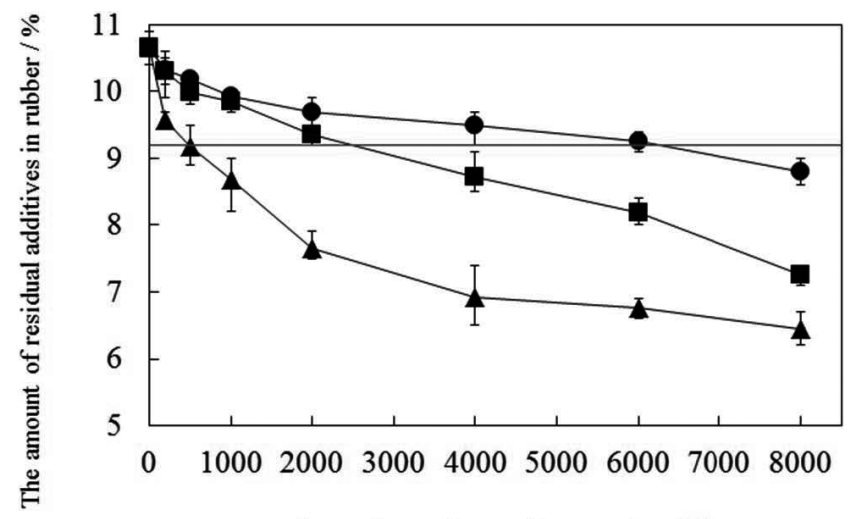

Time of accelerated heat aging $(\mathrm{h})$

, Accelerated heat aging at $60^{\circ} \mathrm{C} ; \boldsymbol{w}$, Accelerated heat aging at $70^{\circ} \mathrm{C}$; $\boldsymbol{\Delta}$, Accelerated heat aging at $80^{\circ} \mathrm{C}$.

Figure 11 The amount of residual additives in rubber during heat aging

\section{2 膜式ガスメーター器差変化の再現試験}

新品および促進劣化試験後の膜式ガスメーターの計量室 体積の測定結果をFigure 8 に示し，器差の測定結果を Figure 9 に示す．図中の值は，各供試メーター5台の平均 值である。

Figure 8から，膜式ガスメーターを静止状態にて行った 熱加速試験後の計量室体積は，新品の値と比べて縮小傾向 にあることがわかった。その程度は，70 ${ }^{\circ} \mathrm{C} 4000$ 時間がよ り顕著であった。駆動部耐久試験後の計量室体積は，室温 および50 ${ }^{\circ} \mathrm{C} て ゙$ 行った結果ともに，新品の值と比べて顕著 な変化が生じないことがわかった。

Figure 9から，膜式ガスメーターを静止状態にて行った 熱加速試験後の器差はプラス側に変化し，室温および50 ${ }^{\circ} \mathrm{C}$ で行った駆動部耐久試験後の器差はマイナス側に変化す ることが確認された。熱加速試験では計量室体積が縮小し ていることから，本来よりも多く吸気・排気工程を繰り返 し，プラス側に器差変化したと考えられる。一方，駆動部 耐久試験では計量室体積が顕著に変化していないことか ら，マイナス側の器差変化はダイヤフラムの経年劣化を主 要因とするものでなく，連動機構を主とする構成部品の機

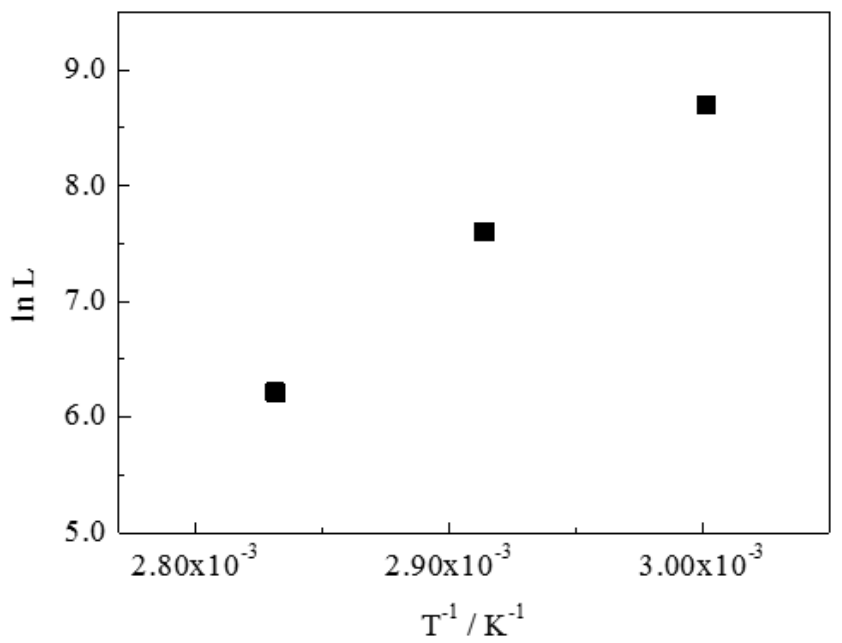

Figure 12 Arrhenius plot of decrease behavior of residual additives

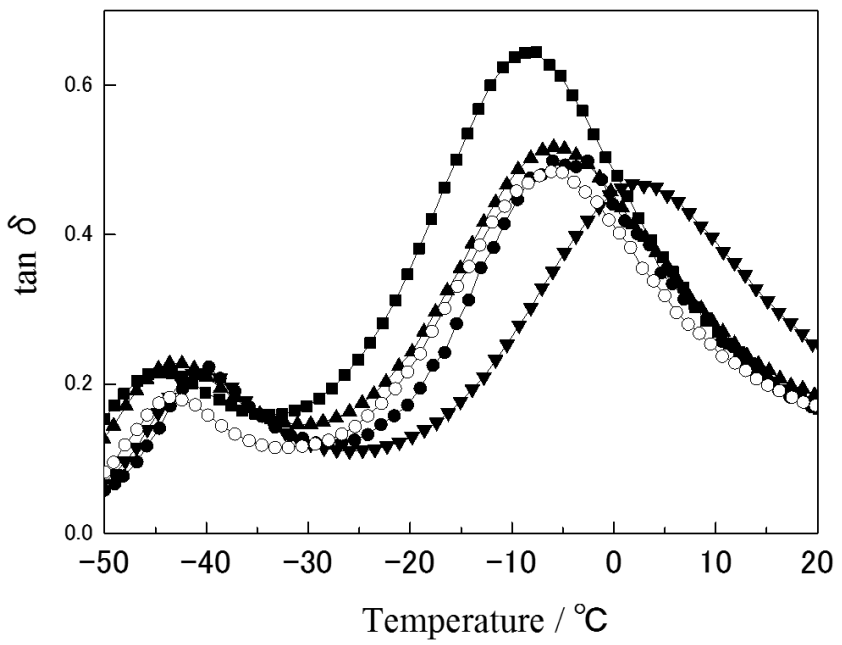

A diaphragm having undergone heat aging at $70^{\circ} \mathrm{C}$ for $\boldsymbol{\square}, 0 \mathrm{~h} ; \boldsymbol{\Delta}, 1000 \mathrm{~h} ; \mathbf{O}, 2000 \mathrm{~h} ; \boldsymbol{\nabla}, 4000 \mathrm{~h}$.

O, A diaphragm used for 20 years

Figure 13 Tangent delta of diaphragm material used for 20 years and those after accelerated degradation test

械的摩耗によるものと推測される.

促進劣化試験後の膜式ガスメーターを分解しダイヤフラ ムを取り出し，市場回収品で散見された「しわ」の発生有 無を確認した。膜式ガスメーターを静止状態にて行った $70{ }^{\circ} \mathrm{C} 2000$ 時間時点の熱加速試験品，室温での 4000 時間 の駆動部耐久試験品, 比較対象として 20 年使用品のダイ ヤフラムの外観写真を Figure 10 に示す.ダイヤフラムの 周辺部分において，20年使用品に類似した形状の「しわ」 が，熱加速試験品に確認された。一方で，駆動部耐久試験 品に顕著な外観上の変化は確認されなかった。

膜式ガスメーターのプラス側の器差変化は, 膜式ガスメ ーターを静止状態にて行った熱加速試験により再現するこ とができた。また，プラス側の器差変化の主要因はダイヤ フラムの熱劣化であり，ダイヤフラムのゴムの硬化・収縮 
により計量室体積が縮小した結果であることを示唆する試 験結果が得られた。

\section{3 ダイヤフラムの熱加速試験の条件最適化}

熱加速試験でのゴム中の添加剤の残存量の推移を Figure 11 に示す．温度の影響により可塑剂等の揮発が促進さ れ, ゴム中の添加剤の残存量が減少する様子が確認できる. Table 1 に示すように，市場回収品調査における20年使用 品での值の最小值は $9.2 \%$ \%あった。大阪ガス管内でのダ イヤフラムの使用期限が 20 年であることから，ガスメー ター設置環境下で 20 年相当の熱負荷が加わる期間をダイ ヤフラムの寿命と考え，ゴム中の添加剤の残存量が $9.2 \%$ に達する時間を各温度で求めた。 20 年使用品との比較か ら，ダイヤフラムの寿命 $L$ は， $60{ }^{\circ} \mathrm{C}$ で 6000 時間， $70{ }^{\circ} \mathrm{C}$ で 2000 時間， $80{ }^{\circ} \mathrm{C}$ で500時間であることがわかった．また， アレニウス則を適用してプロットした結果を Figure 12 に 示す. 図は $60{ }^{\circ} \mathrm{C}, 70{ }^{\circ} \mathrm{C}, 80{ }^{\circ} \mathrm{C}$ の絶対温度の逆数に対し, ダイヤフラムの寿命 $L$ の自然対数をプロットしており，3 点は直線でよく近似できている．Figure 12 から傾きを読 み取り，見かけ上の活性化エネルギーを算出すると $1.21 \times$ $10^{5} \mathrm{~J} / \mathrm{mol}$ であることがわかった。この值は, 従来報告さ れている NBR 等の耐熱寿命試験における活性化エネルギ ー10-11) と近い值であった。

ダイヤフラムの熱加速試験品の動的粘弾性測定の結果を Figure 13 に示す。比較対象として，20年使用品の值を図 中に示した. 20 年相当と考えられる $70{ }^{\circ} \mathrm{C} 2000$ 時間の熱加 速試験品は，損失正接 $\tan \delta$ の高温側のピークが- $5{ }^{\circ} \mathrm{C}$ 付 近であり，20年使用品の值と同等であることが確認され た。

ダイヤフラムの基布の主成分である PETのガラス転移 温度が $70{ }^{\circ} \mathrm{C}$ 近辺であることを考慮すると，ダイヤフラム の 20 年相当の経年劣化は, $70{ }^{\circ} \mathrm{C}$ で 2000 時間もしくは 60 ${ }^{\circ} \mathrm{C}$ で 6000 時間の熱加速試験により再現可能と考えられる.

\section{5. 結言}

膜式ガスメーターのプラス側の器差変化を再現可能な評
価手法を構築するため, 市場回収品の分解調査を行い，プ ラス側の器差変化の主要因を調べた. その後，プラス側の 器差変化の再現試験に取り組み，20年相当の促進劣化試 験の条件検討を行った。その結果, プラス側の器差変化の 主要因はダイヤフラムの熱劣化であることを見出し，プラ ス側の器差変化を膜式ガスメーターを静止状態にて行った 熱加速試験により再現することができた。また，ダイヤフ ラムの 20 年相当の熱加速試験条件は, $70{ }^{\circ} \mathrm{C} て ゙ 2000$ 時間も しくは $60{ }^{\circ} \mathrm{C} て ゙ 6000$ 時間であることが明らかとなった.

\section{References}

1 ) Yamada, T.: Musashi Kogyo Daigaku Kankyo Joho Gakubu Kiyo, 10, 100 (2009)

2 ) Ozawa, Y.; Nishimura, H.; Kawaguchi, T.; Yamaguchi, H.: International Gas Research Conference 2008, 254, Paris (2008)

3 ) Ozawa, Y.; Kawaguchi, T.; Yamaguchi, H.: 40 ${ }^{\text {th }}$ Shinraisei Hozensei Symposium Happyo Hobunshu, 149 (2010)

4 ) Ozawa, Y.; Kawaguchi, T.: International Gas Research Conference 2011, 2, Seoul (2011)

5 ) Ozawa, Y.; Yamaguchi, H.; Nishimura, H.: $23^{\text {th }}$ The Japan Society of. Polymer Processing Nenjitaikai Yoshishu, 273 (2012)

6 ) Ozawa, Y.; Asada, A.; Nishimura, H.: Material Life Gakkaishi, 25, 12 (2013)

7 ) Itakura, T.: Report of the National Research Laboratory of Metrology, 32, 289 (1983)

8 ) Mikami, M.; Shimizu, Y.: INSS journal, 13, 216 (2006)

9 ) Yamada, N., : Nippon Gomu Kyokaishi, 82 (1), 30 (2009)

10) Nishizawa, H.: Polyfile, 48 (3), 63 (2011)

11) Fujii, Y.; Mitsuta, Y.: INSS journal, 10, 99 (2003)

\section{日本語表記参考文献}

1 ）山田哲男：武蔵工業大学環境情報学部紀要，10, 100 (2009)

3 ）小澤由規, 川口隆文, 山口秀樹：第 40 回信頼性・保全性シンポ ジウム発表報文集，149（2010）

5 ）小澤由規, 山口秀樹, 西村寞之：第23 回プラスチック成形加工 学会年次大会予稿集，273（2012）

6 ）小澤由規, 浅田昭治, 西村寛之：マテリアルライフ学会誌，25, 12 (2013)

7 ）板倉民雄, 計量研究所報告, 32, 289 (1983)

8 ）三上雅生，清水泰貴：INSS journal，13, 216 （2006）

9 ）山田聿男，日本ゴム協会誌，82（1）, 30（2009）

10）西澤仁, Polyfile, 48 (3), 63 (2011)

11）藤井有蔵，満田安正：INSS journal， 10, 99 (2003) 